\title{
RELATIONSHIP BETWEEN FUNCTION AND PRESENCE AND TYPE OF DEFORMITY IN PATIENTS WITH CEREBRAL PALSY
}

\author{
RELAÇÃO ENTRE A FUNÇÃO E A PRESENÇA E TIPO DE DEFORMIDADE NO PACIENTE \\ COM PARALISIA CEREBRAL
}

\author{
RELACIÓN ENTRE LA FUNCIÓN Y LA PRESENCIA Y TIPO DE DEFORMIDAD \\ EN PACIENTES CON PARÁLISIS CEREBRAL
}

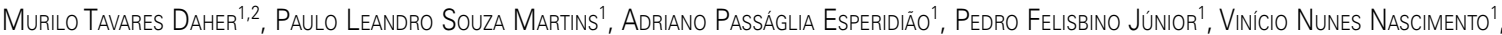

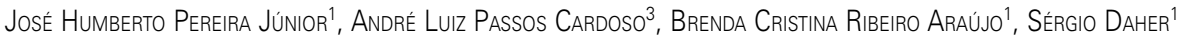 \\ 1. Centro de Reabilitação e Readaptação Dr. Henrique Santillo (CRER - Goiânia/GO), Goiânia, GO, Brazil. \\ 2. Faculdade de Medicina da Universidade Federal de Goiás (DOT/FM/UFG), Department of Orthopedics and Traumatology, Spine Group, Goiânia, GO, Brazil. \\ 3. Universidade Federal de Goiás (HC/UFG), Hospital das Clínicas, Goiânia, GO, Brazil.
}

\begin{abstract}
Objective: To evaluate the gross motor function (GMFCS) with respect to the prevalence and type of scoliosis in patients with cerebral palsy (CP). Methods: This was an analytical, cross-sectional study. We evaluated medical records and imaging studies of 100 patients randomly assigned to a specialist rehabilitation center for the care of such patients. The patients were classified according the gross motor function (GMFCS) and those with deformities were classified as per the kind of scoliosis through the classification of Lonstein and Akbarnia). A correlation was made among the presence of deformity, the variables of the type of deformity and motor function by GMFCS. Results: Of the 100 patients evaluated, 69 had scoliosis. The mean age of patients with scoliosis was higher than that of patients without deformity (12.63 and 10.46 years). Thirty-nine (57\%) patients had spastic tetraparesis and $32(46 \%)$ spastic diparesis. The most frequent curve pattern was the thoracolumbar and the average angular value of the main curve was 27 degrees. There was a positive correlation between the presence of scoliosis and GMFCS level V. There was also a positive correlation between the Lonstein Group II and GMFCS V. Conclusion: There is a positive correlation between the presence of scoliosis and greater involvement of gross motor function (GMFCS V). In patients with deformities, there is also a positive correlation between the Group II of Lonstein and GMFCS V.
\end{abstract}

Keywords: Spine; Cerebral palsy; Scoliosis; Epidemiology.

RESUMO

Objetivo: Avaliar a função motora grossa (GMFCS) com relação à prevalência e ao tipo de escoliose no paciente com paralisia cerebral (PC). Métodos: Estudo transversal analítico. Foram avaliados prontuários e exames de imagem de 100 pacientes escolhidos aleatoriamente em centro de reabilitação especializado no cuidado desse tipo de paciente. Os pacientes foram classificados de acordo com a função motora (GMFCS) e os que tinham deformidade foram classificados de acordo com o tipo da escoliose, segundo a classificação de Lonstein e Akbarnia. Foi feita uma correlação entre a presença de deformidade, as diversas variáveis entre o tipo de deformidade e a função motora pelo GMFCS. Resultados: Dos 100 pacientes avaliados, 69 apresentavam escoliose. A média de idade entre os pacientes com escoliose foi superior à dos pacientes sem deformidade (12,63 e 10,46 anos). Trinta e nove (57\%) pacientes apresentavam tetraparesia espástica e 32 (46\%) diparesia espástica. O padrão de curva mais frequente foi o toracolombar e o valor angular médio da curva principal foi de 27 graus. Houve uma correlação positiva entre a presença de escoliose e GMFCS nível V. Também houve correlação positiva entre o Grupo II de Lonstein e GMFCS V. Conclusão: Existe uma correlação positiva entre a presença de escoliose e maior acometimento da função motora grossa (GMFCS V). Nos pacientes com deformidades, também existe uma correlação positiva entre o Grupo II de Lonstein e o GMFCS V.

Descritores: Coluna vertebral; Paralisia cerebral; Escoliose; Epidemiologia.

\section{RESUMEN}

Objetivo: Evaluar la función motora gruesa (GMFCS) con respecto a la prevalencia y tipo de escoliosis en pacientes con parálisis cerebral (PC). Métodos: Estudio transversal analítico. Se evaluaron los registros médicos y los estudios de imagen de 100 pacientes asignados al azar en un centro de rehabilitación especializado en el cuidado de estos pacientes. Los pacientes fueron clasificados de acuerdo con la función motora (GMFCS) y aquellos con deformidad se clasificaron según el tipo de escoliosis, de acuerdo con Lonstein y Akbarnia. Se hizo una correlación entre la presencia de deformidad, las variables del tipo de deformidad y la función motora por GMFCS. Resultados: De los 100 pacientes evaluados, 69 tenían escoliosis. La edad promedio de los pacientes con escoliosis fue mayor que la de los pacientes sin deformidad (12,63 y 10,46 años). Treinta y nueve (57\%) pacientes tuvieron tetraparesia espástica y 32 (46\%) diparesia espástica. El patrón de la curva más frecuente fue el toracolumbar y el promedio del valor angular de la curva principal era de 27 grados. Hubo una correlación positiva entre la presencia de escoliosis y el nivel V GMFCS. También hubo una correlación positiva entre las curvas del Grupo II de Lonstein y GMFCS V. Conclusión: Existe una correlación positiva entre la presencia de escoliosis y un mayor comprometimiento de la función motora gruesa (GMFCS V). En los pacientes con deformidades, también existe una correlación positiva entre el Grupo /l de Lonstein y GMFCS V.

Descriptores: Columna vertebral; Parálisis cerebral; Escoliosis; Epidemiología. 


\section{INTRODUCTION}

The patient with cerebral palsy (CP) has a high risk of presenting scoliosis. ${ }^{1}$ Its prevalence varies from 15 to $80 \%$, depending on the definition of scoliosis used, the age, and the severity of the neurological involvement. ${ }^{1,2}$ The degree of neurological involvement is usually classified according to the type of lesion (spasticity, dyskinesia, and ataxia) and the location (hemiplegia, diplegia, or tetraplegia). ${ }^{1,3}$

The main classification for motor function is accomplished using the Gross Motor Function Classification System (GMFCS) that divides patients into five levels according to locomotion capacity. ${ }^{4}$ However, most studies that consider the prevalence of vertebral deformity either predate the development of this classification system or do not take it into account. ${ }^{5-7}$

The type of scoliosis found in patients with CP also varies according the presentation of the disease. The most used classification is that of Lonstein and Akbarnia, with Group I being more prevalent in ambulatory patients and Group II in nonambulatory patients. ${ }^{8}$ There is no study in the literature that considers both the type of deformity and the GMFCS motor function.

The objective of this study is to evaluate motor function in relation to the prevalence and the type of deformity according to the Lonstein classification

\section{METHOD}

This is a cross-sectional analytical study. Following approval by the Institutional Review Board as number 52871115.1.0000.0023, the medical records and exams of 100 patients (Table 1) who were in outpatient follow-up in a rehabilitation center specializing in the care of this type of patient (CRER - Centro de Reabilitação e Readaptação Dr. Henrique Santillo - Goiânia - GO) were evaluated. The patients were chosen randomly from all the patients with a primary diagnosis of $\mathrm{CP}$ in the electronic medical records system.

Table 1. Demographic data, presence or absence of scoliosis, degree of neurological involvement, and function according to the GMFCS.

\begin{tabular}{|c|c|c|c|c|c|}
\hline Patient & Sex & Age & $\begin{array}{c}\text { Presence of } \\
\text { scoliosis }\end{array}$ & Type of CP & GMFCS \\
\hline 1 & Female & 16.41 & Negative & Diparetic spastic CP & 2 \\
\hline 2 & Female & 14.00 & Positive & Diparetic spastic CP & 4 \\
\hline 3 & Male & 16.19 & Negative & Hemiparetic spastic CP & 1 \\
\hline 4 & Female & 5.21 & Positive & Diparetic spastic CP & 5 \\
\hline 5 & Male & 9.98 & Negative & Hemiparetic spastic CP & 2 \\
\hline 6 & Male & 7.37 & Positive & Diparetic spastic CP & 5 \\
\hline 7 & Female & 6.49 & Negative & Hemiparetic spastic CP & 3 \\
\hline 8 & Male & 10.74 & Negative & Hemiparetic spastic CP & 2 \\
\hline 9 & Male & 12.97 & Positive & Tetraparetic spastic CP & 4 \\
\hline 10 & Male & 12.19 & Positive & Hemiparetic spastic CP & 4 \\
\hline 11 & Male & 14.63 & Negative & Hemiparetic spastic CP & 5 \\
\hline 12 & Female & 17.33 & Positive & Tetraparetic spastic CP & 4 \\
\hline 13 & Female & 7.66 & Positive & Tetraparetic dyskinetic CP & 5 \\
\hline 14 & Female & 11.21 & Negative & Diparetic spastic CP & 2 \\
\hline 15 & Male & 15.22 & Positive & Diparetic spastic CP & 5 \\
\hline 16 & Male & 7.70 & Negative & Hemiparetic spastic CP & 1 \\
\hline 17 & Male & 8.83 & Positive & Diparetic spastic CP & 5 \\
\hline 18 & Male & 17.05 & Negative & Diparetic spastic CP & 2 \\
\hline 19 & Female & 13.90 & Positive & Diparetic spastic CP & 2 \\
\hline 20 & Female & 8.04 & Positive & Tetraparetic spastic CP & 2 \\
\hline 21 & Female & 7.64 & Positive & Hemiparetic spastic CP & 5 \\
\hline 22 & Male & 14.04 & Positive & Tetraparetic spastic CP & 3 \\
\hline 23 & Male & 8.46 & Negative & Diparetic spastic CP & 2 \\
\hline 24 & Male & 8.04 & Negative & Diparetic spastic CP & 5 \\
\hline 25 & Female & 9.65 & Positive & Diparetic spastic CP & 5 \\
\hline 26 & Female & 15.00 & Positive & Dyskinetic CP & 4 \\
\hline 27 & Male & 13.25 & Negative & Diparetic flaccid CP & 2 \\
\hline 28 & Male & 19.69 & Positive & Tetraparetic spastic CP & 5 \\
\hline 29 & Female & 10.24 & Negative & Hemiparetic spastic CP & 1 \\
\hline 30 & Male & 8.37 & Negative & Tetraparetic spastic CP & 2 \\
\hline 31 & Male & 13.37 & Positive & Diparetic spastic CP & 5 \\
\hline 32 & Male & 8.67 & Negative & Tetraparetic spastic CP & 5 \\
\hline
\end{tabular}

\begin{tabular}{|c|c|c|c|c|c|}
\hline Patient & Sex & Age & \begin{tabular}{|c|} 
Presence of \\
scoliosis
\end{tabular} & Type of CP & GMFCS \\
\hline 33 & Male & 18.69 & \begin{tabular}{|l|} 
Positive \\
\end{tabular} & Tetraparetic spastic CP & 5 \\
\hline 34 & Male & 8.61 & Negative & Diparetic spastic CP & 1 \\
\hline 35 & Male & 8.55 & Positive & Diparetic spastic CP & 5 \\
\hline 36 & Male & 9.14 & Negative & Tetraparetic dyskinetic CP & 5 \\
\hline 37 & Male & 17.69 & Positive & Tetraparetic spastic CP & 5 \\
\hline 38 & Male & 16.39 & Positive & Diparetic spastic CP & 5 \\
\hline 39 & Female & 8.66 & Negative & Tetraparetic spastic CP & 2 \\
\hline 40 & Female & 7.88 & Negative & Hemiparetic spastic CP & 4 \\
\hline 41 & Female & 14.97 & Positive & Diparetic spastic CP & 1 \\
\hline 42 & Female & 11.74 & Positive & Tetraparetic spastic CP & 4 \\
\hline 43 & Male & 6.11 & Negative & Tetraparetic spastic CP & 1 \\
\hline 44 & Male & 7.82 & Positive & Diparetic spastic CP & 2 \\
\hline 45 & Male & 12.83 & Positive & Tetraparetic spastic CP & 5 \\
\hline 46 & Male & 16.50 & Positive & Tetraparetic spastic CP & 3 \\
\hline 47 & Male & 17.61 & Positive & Diparetic spastic CP & 5 \\
\hline 48 & Male & 23.87 & Positive & Tetraparetic spastic CP & 2 \\
\hline 49 & Male & 9.23 & Positive & Diparetic spastic CP & 1 \\
\hline 50 & Male & 12.50 & Negative & Tetraparetic spastic CP & 4 \\
\hline 51 & Male & 12.25 & Positive & Hemiparetic spastic CP & 5 \\
\hline 52 & Male & 19.39 & Positive & Tetraparetic spastic CP & 5 \\
\hline 53 & Male & 16.43 & Negative & Diparetic spastic CP & 2 \\
\hline 54 & Male & 8.46 & Positive & Diparetic spastic CP & 5 \\
\hline 55 & Female & 7.55 & Positive & Tetraparetic dyskinetic CP & 5 \\
\hline 56 & Female & 7.35 & Positive & Dyskinetic CP & 5 \\
\hline 57 & Male & 14.06 & Positive & Tetraparetic spastic CP & 5 \\
\hline 58 & Male & 18.29 & Positive & Diparetic spastic CP & 3 \\
\hline 59 & Male & 16.27 & Positive & Hemiparetic spastic CP & 5 \\
\hline 60 & Male & 14.25 & Positive & Tetraparetic spastic CP & 2 \\
\hline 61 & Male & 14.27 & Positive & Diparetic spastic CP & 2 \\
\hline 62 & Male & 16.65 & Positive & Tetraparetic spastic CP & 4 \\
\hline 63 & Female & 8.15 & Positive & Hemiparetic spastic CP & 4 \\
\hline 64 & Female & 14.24 & Positive & Tetraparetic spastic CP & 5 \\
\hline 65 & Female & 7.96 & Positive & Tetraparetic spastic CP & 4 \\
\hline 66 & Female & 7.27 & Positive & Diparetic spastic CP & 4 \\
\hline 67 & Male & 7.26 & Positive & Hemiparetic spastic CP & 5 \\
\hline 68 & Male & 7.23 & Positive & Tetraparetic spastic CP & 5 \\
\hline 69 & Female & 7.49 & Negative & Tetraparetic spastic CP & 5 \\
\hline 70 & Male & 14.90 & Positive & Tetraparetic dyskinetic CP & 2 \\
\hline 71 & Female & 9.62 & Negative & Tetraparetic spastic CP & 5 \\
\hline 72 & Female & 16.06 & Positive & Tetraparetic dyskinetic CP & 2 \\
\hline 73 & Female & 9.11 & Positive & Diparetic spastic CP & 3 \\
\hline 74 & Female & 12.61 & Negative & Tetraparetic spastic CP & 1 \\
\hline 75 & Female & 11.87 & Positive & Tetraparetic spastic CP & 2 \\
\hline 76 & Male & 9.10 & Positive & Hemiparetic spastic CP & 4 \\
\hline 77 & Male & 7.30 & Positive & Tetraparetic spastic CP & 2 \\
\hline 78 & Male & 4.64 & Positive & Dyskinetic CP & 1 \\
\hline 79 & Female & 10.20 & Negative & Diparetic spastic CP & 4 \\
\hline 80 & Male & 13.49 & Positive & Dyskinetic CP & 5 \\
\hline 81 & Male & 10.80 & Positive & Tetraparetic spastic CP & 5 \\
\hline 82 & Female & 6.42 & Negative & Diparetic flaccid CP & 4 \\
\hline 83 & Male & 19.11 & Positive & Diparetic spastic CP & 5 \\
\hline 84 & Male & 11.57 & Positive & Diparetic spastic CP & 5 \\
\hline 85 & Female & 9.80 & Negative & Tetraparetic spastic CP & 5 \\
\hline 86 & Male & 8.31 & Positive & Hemiparetic spastic CP & 5 \\
\hline 87 & Male & 19.14 & Positive & Tetraparetic spastic CP & 5 \\
\hline 88 & Female & 8.91 & Positive & Tetraparetic spastic CP & 5 \\
\hline 89 & Female & 7.12 & Positive & Tetraparetic spastic CP & 3 \\
\hline 90 & Male & 14.48 & Positive & Tetraparetic spastic CP & 5 \\
\hline 91 & Female & 36.29 & Positive & Tetraparetic dyskinetic CP & 5 \\
\hline 92 & Male & 7.82 & Positive & Tetraparetic dyskinetic CP & 2 \\
\hline 93 & Female & 9.63 & Negative & Hemiparetic spastic CP & 5 \\
\hline 94 & Female & 8.21 & Positive & Tetraparetic spastic CP & 5 \\
\hline 95 & Female & 14.27 & Positive & Diparetic spastic CP & 1 \\
\hline 96 & Male & 10.36 & Negative & Tetraparetic spastic CP & 1 \\
\hline 97 & Male & 14.49 & Positive & Tetraparetic spastic CP & 1 \\
\hline 98 & Male & 11.37 & Negative & Diparetic spastic CP & 4 \\
\hline 99 & Male & 13.57 & Positive & Diparetic flaccid CP & 5 \\
\hline 100 & Female & 12.10 & Positive & Tetraparetic spastic CP & 2 \\
\hline
\end{tabular}


All the patients were classified by level of locomotion and motor function using the GMFCS ${ }^{4}$ in consultations with the physiatrist and the neurologist. (Table 2)

All the patients had full spine radiographs in anteroposterior and lateral views that were taken as scoliosis screening exams during routine evaluation by the physiatric team. The radiographs were taken with ambulatory patients standing and with nonambulatory patients sitting. The radiographic evaluation assessed the presence or absence of scoliosis (deformity in the coronal plane greater than 10 degrees by the Cobb method), the presence of pelvic obliquity (PO), the type of curve, and the presence or absence of trunk imbalance in the sagittal plane. The trunk was considered in balance when a plumb line from $\mathrm{C} 7$ fell on the upper plateau of S1, anteriorly decompensated when it fell in front, and posteriorly decompensated when it fell behind. ${ }^{9}$

The patients with scoliosis were also classified during the evaluation according to the Lonstein and Akbarnia classification system ${ }^{8}$ as shown in Figure 1.

A logistic regression test was performed to evaluate the correlation between the presence or absence of scoliosis and the different variables and the chi square test was used to assess the relationship between the Lonstein classification and the GMFCS level (SPSS for Windows, version 15.0). The significance level was set at $5 \%$ and values of $p$-value less than 0.05 were considered to be statistically significant.

Table 2. Classification of Gross Motor Function (GMFCS)

\begin{tabular}{|c|c|c|}
\hline Level I & $\begin{array}{l}\text { Walks without restrictions, with } \\
\text { limitations for running and jumping. }\end{array}$ & \\
\hline Level II & $\begin{array}{l}\text { Walks with assistance from small } \\
\text { appliances and/or crutches, with slight } \\
\text { community ambulation limitations. }\end{array}$ & Bif \\
\hline Level III & $\begin{array}{c}\text { Walks with the assistance of walker } \\
\text { and/or crutches, with community } \\
\text { ambulation difficulties. }\end{array}$ & की $\theta$ की \\
\hline Level IV & $\begin{array}{l}\text { Walks with the assistance of walker } \\
\text { but with limitations and requires a } \\
\text { wheelchair for community ambulation. }\end{array}$ & 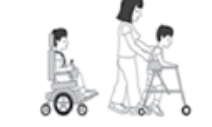 \\
\hline Level V & $\begin{array}{l}\text { Severely limited mobility, even with } \\
\text { appliances and adaptations, with } \\
\text { wheelchair adaptations required. }\end{array}$ & $\theta_{0} \rightarrow \theta_{0}^{\infty}$ \\
\hline
\end{tabular}

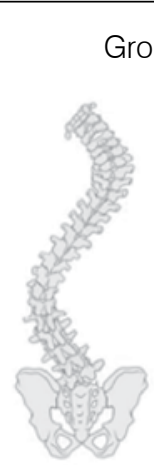

IA
$\| \mathrm{A}$

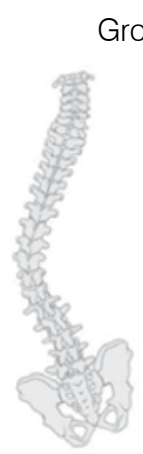

\section{Group $\|$}

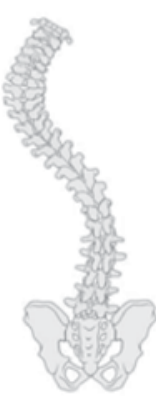

IB

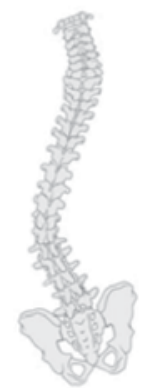

IIB
Figure 1. Lonstein and Akbarnia Classification. Group I is characterized by a compensated trunk (IA double curve and IB thoracic) and Group by a decompensated trunk with pelvic obliquity (IIA fractionated curve above the sacrum and IIB with the sacrum making up part of the principal curve).

\section{RESULTS}

Table 1 displays the demographic data of the patients. Of the 100 patients evaluated, 61 were male and 39 were female. The average age was 11.96 (SD 4.68) years, ranging from 4 to 36 . The prevalence of scoliosis was $69 \%$. Of the 69 patients with deformity, 43 (62.3\%) were male and their average age was 12.63 (SD 5.12), statistically higher than the group without deformity $(p<0.05)$.

Regarding the degree of neurological involvement, 39 (57\%) patients presented spastic tetraparesis, 32 (46\%) presented spastic diparesis, 15 (22\%) spastic hemiparesis, and 6 (9\%) dyskinetic tetraparesis. (Table 1).

In terms of motor function, most of patients with scoliosis were classified as levels IV and V according to the GMFCS, with a statistically significant correlation with type $V(p=0.04$, OR 1.54). (Table 3)

In the radiographic evaluation, the most frequent types of curves were thoracolumbar (24 out of 69 cases) and lumbar (18 out of 69 cases). (Figure 2) The average angle of the principal curve was 27 degrees, ranging from 10 to 77 degrees. PO was present in $75 \%$ (52 out of 69 ) of the patients with scoliosis, with an average angular value of 8.4 degrees (minimum of 3 and maximum of 21). In the sagittal plane, 30 (43\%) patients presented anterior trunk imbalance, $18(26.1 \%)$ presented posterior trunk imbalance, and $21(30.4 \%)$ were in balance.

As for the type of deformity, 40 patients were in group 1A, 13 in group IB, two in group IIA, and 14 in group IIB. Table 4 shows that there was a statistical correlation between group II and GMFCS motor function level V. Fifteen of the 16 patients with group II deformities presented GMFCS IV or V. (Table 4)

Table 3. Relationship between gross motor function and the presence or absence of deformity.

\begin{tabular}{|c|c|c|c|c|c|c|c|c|}
\hline \multirow{2}{*}{ Scoliosis } & \multicolumn{2}{|c|}{ Negative } & \multicolumn{2}{|c|}{ Positive } & \multirow{2}{*}{ p } & \multirow{2}{*}{ OR } & \multicolumn{2}{|c|}{ Cl $95 \%$} \\
\hline & $\mathrm{n}$ & $\%$ & $\mathbf{n}$ & $\%$ & & & Min & Max \\
\hline \multicolumn{9}{|l|}{ GMFCS } \\
\hline I & 7 & 22.6 & 5 & 7.2 & & & & \\
\hline II & 10 & 32.3 & 12 & 17.4 & & & & \\
\hline III & 1 & 3.2 & 5 & 7.2 & & & & \\
\hline IV & 5 & 16.1 & 11 & 15.9 & & & & \\
\hline V & 8 & 25.8 & 36 & 52.2 & & & & \\
\hline Total & 31 & 100.0 & 69 & 100.0 & 0.004 & 1.54 & 1.15 & 2.06 \\
\hline
\end{tabular}

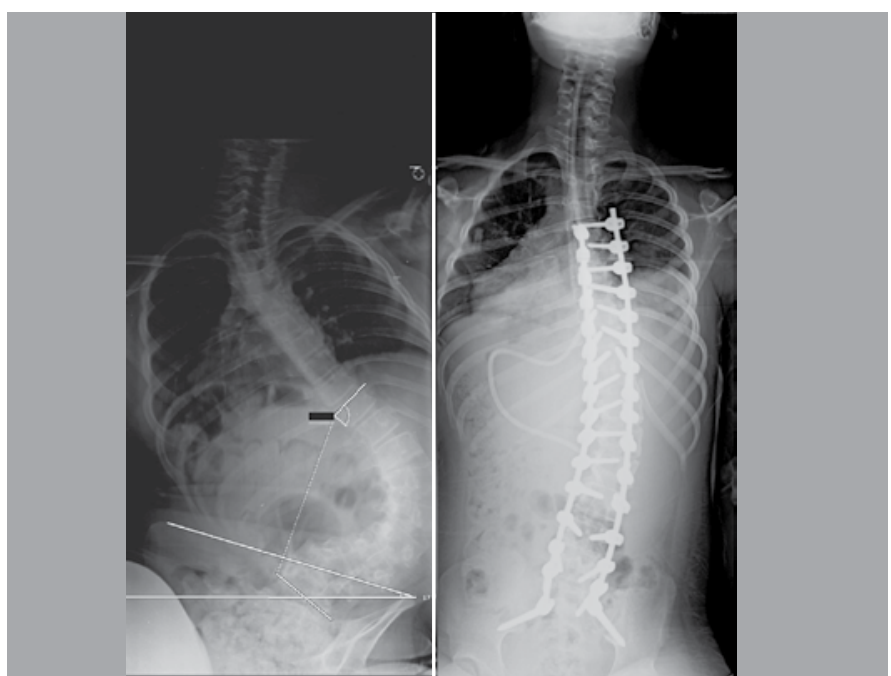

Figure 2. Example of a patient with diparetic spastic CP, with lumbar scoliosis (apex L3) on the right and PO with elevation of the left hemipelvis. This is an example of a type IIA curve since there is a fractionated lumbosacral curve with the pelvis not being part of the curve. This patient underwent surgical treatment with correction of the curve and arthrodesis from T4 to the ilium. 
Table 4. Correlation between the type of deformity and the GMFCS motor function.

\begin{tabular}{c|c|c|c|c|c|c|c|c|c}
\hline \multirow{2}{*}{$\begin{array}{c}\text { Lonstein } \\
\text { Classification }\end{array}$} & \multicolumn{2}{|c|}{ I A } & \multicolumn{2}{|c|}{ I B } & \multicolumn{2}{|c|}{ II A } & \multicolumn{2}{|c|}{ II B } & \multirow{2}{*}{ p } \\
\cline { 2 - 9 } & $\mathbf{n}$ & $\%$ & $\mathbf{n}$ & $\%$ & $\mathbf{n}$ & $\%$ & $\mathbf{n}$ & $\%$ & \\
\hline GMFCS & & & & & & & & & \\
\hline I & 3 & 7.5 & 1 & 7.7 & 1 & 50.0 & 0 & 0.0 & \\
\hline II & 10 & 25.0 & 2 & 15.4 & 0 & 0.0 & 0 & 0.0 & \\
\hline III & 4 & 10.0 & 1 & 7.7 & 0 & 0.0 & 0 & 0.0 & \\
\hline IV & 9 & 22.5 & 0 & 0.0 & 0 & 0.0 & 2 & 14.3 & \\
\hline V & 14 & 35.0 & 9 & 69.2 & 1 & 50.0 & 12 & 85.7 & \\
\hline Total & $\mathbf{4 0}$ & $\mathbf{1 0 0 . 0}$ & $\mathbf{1 3}$ & $\mathbf{1 0 0 . 0}$ & $\mathbf{2}$ & $\mathbf{1 0 0 . 0}$ & $\mathbf{1 4}$ & $\mathbf{1 0 0 . 0}$ & $\mathbf{0 . 0 4 6}$ \\
\hline
\end{tabular}

\section{DISCUSSION}

Scoliosis in cerebral palsy is a complex deformity and treating it is quite demanding for the spine surgeon. ${ }^{10-12}$ Most studies correlate the presence of scoliosis with the degree of neurological involvement ${ }^{2,5-7}$ and few correlate the deformity with any type of functional classification such as the GMFCS. ${ }^{1}$ In addition, no study correlates the type of deformity to motor function.

Perrson-Bunke et al. ${ }^{1}$ evaluated a population in southern Sweden and observed an incidence of scoliosis of 192 cases among 666 children with CP. This screening was performed based on a physical examination of the patients, which could justify the much lower incidence than that found in our population. Another factor is that our case series consists of patients who are undergoing outpatient follow-up in an institution specializing in the treatment of this type of pathology, while the study in question is based on a register of the population. Radiographs were performed in 76 of these patients, in which predominantly thoracolumbar curves were observed, most of them between 21 and 40 degrees, similar to those found in our population.
This same study ${ }^{1}$ showed that there is a positive correlation between the level of involvement according to the GMFCS and the presence of deformity that is more significant than the type and topography of the CP involvement. In fact, the higher prevalence of scoliosis among the patients with spastic tetraparesis or dyskinesia is justified by the high prevalence of patients with GMFCS types IV and V in these CP subtypes. These findings are in agreement with those found in our case series. However, this study did not take the presence of PO or the type of deformity into account and we know that they are important factors in the reduction of function in patients with $\mathrm{CP}^{13}$

Lonstein and Akbarnia ${ }^{8}$ described the curve patterns affecting patients with CP and mental retardation in 1983. In their original study, they observed a higher prevalence of group I deformities (balanced double curves) among patients with mental retardation and of group II deformities (imbalanced lumbar or thoracolumbar curves) among nonambulatory patients and those with PO. Our study was the first to correlate the type of curve with motor function and, just as with the presence or absence of deformity, there was a positive correlation between group II deformities and patients classified as GMFCS V.

Loeters et al. ${ }^{14}$ conducted a literature review on the risk factors for the progression of scoliosis in patients with CP. Based on 10 studies, they failed to demonstrate any specific risk factor with a high level of evidence. They only suggested a possible relationship to the severity of the pathology. They concluded their review, stating that it was very important to conduct new studies based on some functional scale, such as the GMFCS.

\section{CONCLUSION}

The CP patients at GMFCS IV and $\mathrm{V}$ had a higher risk of presenting scoliosis. In addition, these patients had a higher incidence of Lonstein group II deformities with PO.

All the authors declare that there are no potential conflicts of interest regarding this article.

CONTRIBUTIONS OF THE AUTHORS: Each author made significant individual contributions to the development of the manuscript. The principal author, MTD, was the lead surgeon and creator of the study concept. SD is the senior doctor of the group and assisted with the concept and the manuscript. PFJ, VNN, JHPJ, and APE assisted with data collection. BCRA is the monitor of the group's center for studies and helped with the bibliographical review. ALPC and PLSM are members of one of the centers where the study was conducted and contributed to some of the cases.

\section{REFERENCES}

1. Persson-Bunke $M$, Hägglund $G$, Lauge-Pedersen $H$, Wagner $P$, Westbom L. Scoliosis in a total population of children with cerebral palsy. Spine (Phila Pa 1976). 2012;37(12):E708-13.

2. McCarthy JJ, D'Andrea LP, Betz RR, Clements DH. Scoliosis in the child with cerebral palsy. J Am Acad Orthop Surg. 2006;14(6):367-75.

3. Pfeifer LI, Silva DB, Funayama CA, Santos JL. Classification of cerebral palsy: association between gender, age, motor type, topography and Gross Motor Function. Arq Neuropsiquiatr. 2009;67(4):1057-61.

4. Hiratuka E, Matsukura TS, Pfeifer LI. Cross-cultural adaptation of the Gross Motor Function Classification System into Brazilian-Portuguese (GMFCS). Rev Bras Fisioter. 2010;14(6):537-44.

5. Koop SE. Scoliosis in cerebral palsy. Dev Med Child Neurol. 2009;51(Suppl 4):92-8.

6. Saito N, Ebara S, Ohotsuka K, Kumeta H, Takaoka K. Natural history of scoliosis in spastic cerebral palsy. Lancet. 1998;351(9117):1687-92

7. Madigan RR, Wallace SL. Scoliosis in the institutionalized cerebral palsy population. Spine (Phila Pa 1976). 1981;6(6):583-90.

8. Lonstein JE, Akbarnia A. Operative treatment of spinal deformities in patients with cerebral palsy or mental retardation. An analysis of one hundred and seven cases. J Bone Joint Surg Am. 1983;65(1):43-55.
9. Gupta MC, Wijesekera S, Sossan A, Martin L, Vogel LC, Boakes JL, et al. Reliability of radiographic parameters in neuromuscular scoliosis. Spine (Phila Pa 1976). 2007;32(6):691-5 10. Daher MT, Cavali PT, Santo MA, Rossato AJ, Lehoczki MA, Landim E. Correlação entre o número de parafusos e o percentual de correção no tratamento cirúrgico da escoliose neuromuscular. Coluna/Columna. 2009:8(2):105-9.

11. Daher MT, Cavali PT, Santo MA, Rossato AJ, Lehoczki MA, Landim E. Comparison between deformity correction of Luque-Galveston instrumentation and pedicle screw fixation in the surgical treatment. Coluna/Columna. 2009;8(2):110-6.

12. França LCM, Falcon RS, Porto Filho MA, Oliveira MPC, Rugani MG, Costa Faria RG, et al. Tratamento cirúrgico da escoliose neuromuscular no paciente portador de paralisia cerebral com instrumentação tóraco-lombo- pélvica. Coluna/Columna. 2008:7(1):59-64

13. Moon ES, Nanda A, Park JO, Moon SH, Lee HM, Kim JY, et al. Pelvic obliquity in neuromuscular scoliosis: radiologic comparative results of single-stage posterior versus twostage anterior and posterior approach. Spine (Phila Pa 1976). 2011;36(2):146-52

14. Loeters MJ, Maathuis CG, Hadders-Algra M. Risk factors for emergence and progression of scoliosis in children with severe cerebral palsy: a systematic review. Dev Med Child Neurol. 2010;52(7):605-11. 